\title{
Happy Being Me: outcomes of a peer-based body dissatisfaction prevention intervention in young adolescent girls
}

\author{
Sian McLean*, Susan Paxton, Eleanor Wertheim \\ From 2013 ANZAED Conference: Inspiring Change: Person and Context \\ Melbourne, Australia. 23-24 August 2013
}

This study aimed to examine body dissatisfaction and risk factor outcomes following participation in Happy Being $\mathrm{Me}$, a 6-lesson peer-based prevention intervention for young adolescent girls. Participants were 491 female year 7 students randomly allocated to the Happy Being Me intervention condition $(\mathrm{N}=295)$ or control condition $(\mathrm{N}=196)$. Self-report questionnaire data was collected at baseline, post-program, and 6- and 12-month follow-up. Preliminary data analyses for the incomplete sample indicate baseline to 6-month follow-up improvements for internalisation of the thin ideal $(\mathrm{F}=5.38(1,332), \mathrm{p}=$ $.021)$, appearance comparisons $(\mathrm{F}=10.21(1,312), \mathrm{p}=$ $.002)$, and media literacy $(\mathrm{F}=15.98(1,327), \mathrm{p}<.001)$ in the Happy Being Me intervention condition relative to the control condition. Reductions in the intervention condition were not significantly different from the control condition for weight and shape concern $(\mathrm{F}=0.28(1,313), \mathrm{p}=$ $.599)$ or body dissatisfaction $(\mathrm{F}=2.48(1,313), \mathrm{p}=.116)$. Twelve-month follow-up data will be presented for the complete sample. The results from this study provide preliminary evidence for positive outcomes following participation in a classroom delivered multi-component peerbased body dissatisfaction prevention intervention.

This abstract was presented in the Prevention stream of the 2013 ANZAED Conference.

Published: 14 November 2013

doi:10.1186/2050-2974-1-S1-033

Cite this article as: McLean et al:: Happy Being Me: outcomes of a peerbased body dissatisfaction prevention intervention in young adolescent girls. Journal of Eating Disorders 2013 1(Suppl 1):033.

* Correspondence: s.mclean@latrobe.edu.au

School of Psychological Science, La Trobe University, Australia
Submit your next manuscript to BioMed Central and take full advantage of:

- Convenient online submission

- Thorough peer review

- No space constraints or color figure charges

- Immediate publication on acceptance

- Inclusion in PubMed, CAS, Scopus and Google Scholar

- Research which is freely available for redistribution
() Biomed Central 